\title{
Inhibition of CYP450scc expression in dioxin-exposed rat Leydig cells
}

\author{
K P Lai, M H Wong and C K C Wong \\ Department of Biology, Hong Kong Baptist University, Kowloon Tong, Hong Kong, People's Republic of China \\ (Requests for offprints should be addressed to C K C Wong; Email: ckcwong@hkbu.edu.hk)
}

\begin{abstract}
Polychlorinated dibenzo- $p$-dioxins, such as 2,3,7,8tetrachlorodibenzo- $p$-dioxin (TCDD) have been recognized as highly potent developmental and reproductive toxins. We have previously demonstrated effects of TCDD in modulating the expression of rat Sertoli cell secretory products and markers for cell-cell interaction. In this study, we examined the direct biological effects of TCDD in rat Leydig cell primary cultures. Mature rat Leydig cells were purified by Percoll gradient centrifugation and the cell purity was determined by $3 \beta$-hydroxysteroid dehydrogenase ( $3 \beta-\mathrm{HSD})$ staining and a testosterone induction assay. To examine TCDD-induced biological consequences, we measured the changes in the secretion of progesterone and testosterone, as well as transcript levels of some selected steroidogenic enzymes (i.e. StAR, P450scc,
\end{abstract}

$3 \beta-H S D$ and CYP17 $\alpha$ ), in TCDD/human chorionic gonadotropin (hCG) co-treated cells. Our results indicated that TCDD $(0 \cdot 2$ or $2 \mathrm{ng} / \mathrm{ml})$ treatment significantly suppressed hCG (5 or $10 \mathrm{ng} / \mathrm{ml}$ )-induced testosterone secretion. The suppressive effect aligned with a reduction of progesterone secretion $(P<0 \cdot 05)$, as well as a decrease of P450scc mRNA and protein expression $(P<0 \cdot 05)$. The mechanistic action of TCDD was found to be via the reduction of cellular cAMP levels in the hCG-treated cells. This observation was further confirmed, as the TCDD-mediated suppressive effect could be reversed by dibutyryl cAMP co-treatment. The data indicate that TCDD can modulate cAMP signaling in rat Leydig cells to affect the process of steroidogenesis.

Journal of Endocrinology (2005) 185, 519-527

\section{Introduction}

2,3,7,8-Tetrachlorodibenzo-p-dioxin (TCDD), the most toxic man-made compound, is mostly generated as an unintentional by-product from many industrial processes, such as waste incineration, pesticide manufacturing, pulp and paper bleaching. Since dioxin is a fat-soluble compound with a semi-volatile nature, it is ubiquitously present in the environment and can be bioaccumulated in food-chains. In general, the mechanistic toxicity of TCDD is mediated by the nuclear translocation of an aryl hydrocarbon receptor (AhR)/AhR nuclear translocator complex that binds to dioxin-responsive elements or by interfering with various signaling molecules in cells (Reyes et al. 1992, Matsushita et al. 1993, Safe 1995, Schmidt \& Bradfield 1996). On the basis of its action, TCDD is recognized as an endocrine disruptor which can have adverse impacts on mammalian reproductive and developmental processes. Its detrimental effects on gonadal function in humans and animals are well documented.

Using in utero and lactational exposure studies in rodent models, toxicities of TCDD $(\mu \mathrm{g} / \mathrm{kg})$ at the early stage of animal development were reported. In female progenies, TCDD disrupted regular estrous cycles and inhibited the onset of ovulation ( $\mathrm{Li}$ et al. 1995, Salisbury \& Marcinkiewicz 2002). In male offspring, reduction of sperm count per cauda epididymis as well as increases in the number of abnormal sperm produced in adulthood were observed (Mably et al. 1992, Bjerke \& Peterson 1994, Faqi et al. 1998). Most of the male progeny were characterized by a reduced size of sex accessory glands (Mably et al. 1992, Bjerke \& Peterson 1994, Gray et al. 1995, Theobald \& Peterson 1997). Accompanying this, other studies scrutinized the biological consequences for postnatal animals that received an i.p. injection of TCDD $(\mu \mathrm{g} / \mathrm{kg}$ body weight). Those studies demonstrated that TCDD altered the process of testicular steroidogenesis and caused a reduction of Leydig cell volume and number (Johnson et al. 1992, 1994, Wilker et al. 1995). Detrimental effects on Sertoli and germ cells of rat testes, such as reduction of the intercellular contact of neighboring cells, disruption of germ cell development, decrease of spermatogenesis, depletion of antioxidant enzymes and increase in the levels of lipid peroxidation were observed (Rune et al. 1991a, Chahoud et al. 1992, Mably et al. 1992, Peterson et al. 1993, Latchoumycandane et al. 2002a,b). It is generally believed that the adverse effects exerted by TCDD on male reproductive functions are manifold and 
pleiotropic. Yet the understanding of reproductive toxicities of TCDD for testicular function has mostly relied on the in vivo approach of using animal models. Complications in pharmacokinetic distribution, as well as secondary effects attributed to other unidentified factors, may make it difficult to decipher the direct mechanistic toxicities of TCDD to the cells. This is particularly true as AhR is widely expressed in various tissues of animals (Dohr et al. 1996, Thomae et al. 2004). Therefore it is necessary to adopt cell models to determine direct biological effects of TCDD to validate the in vivo findings.

With the benefit of hindsight, the present study aimed to reveal the mechanistic role of TCDD on reproductive disorders with special reference to mammalian Leydig cells. It is well known that Leydig cells play a crucial role in synthesizing testosterone and regulating the process of spermatogenesis. Alteration of cell function can lead to adverse effects on testicular functions. In this study, we aimed to elucidate the effect of TCDD on the process of steroidogenesis and testosterone secretion in Leydig cells. To decipher the mechanistic activities, TCDD-stimulated cytochrome P4501A1 (CYP1A1) expression and mRNAs of the key steroidogenic enzymes, as well as the level of progesterone and testosterone secretion, were measured.

\section{Materials and Methods}

\section{Primary culture of rat Leydig cells}

Leydig cells were isolated from testes of 90- to 120-dayold sexually mature male Sprague-Dawley rats and were cultured for 2 days as described elsewhere (Biegel et al. 1993). All experimental animals were housed, handled and used in accordance with the University guidelines. Briefly, testes were collected and decapsulated from five male rats and were then digested in M199 medium containing $0.5 \mathrm{mg} / \mathrm{ml}$ collagenase and 1\% BSA in Erlenmyer flasks in a $34{ }^{\circ} \mathrm{C}$ oscillating incubator at 100 r.p.m. for $15 \mathrm{~min}$. Digested cell suspensions were transferred to a $50 \mathrm{ml}$ tube and kept on ice for 2 min to allow tubules to settle. The supernatant containing Leydig cells was filtered through cell strainers $(70 \mu \mathrm{m}$ nylon; Falcon, BD Biosciences, Franklin Lakes, NJ, USA) and the cells were then centrifuged at $350 \mathrm{~g}$ for $20 \mathrm{mins}$ at $4{ }^{\circ} \mathrm{C}$. The pellet was re-suspended in $10 \mathrm{ml} \mathrm{M} 199$ and loaded on top of a step Percoll gradient (5, 30, 58 and 70\%) (Sigma). The cell was then centrifuged at $800 \mathrm{~g}$ for $30 \mathrm{mins}$ at $4{ }^{\circ} \mathrm{C}$. Three layers of cell were apparent; the enriched fraction of Leydig cells was found in the third layer. The cells were collected, washed with M199 twice and were finally re-suspended in phenol red free-DMEM/F12 (1:1) medium supplemented with 10\% charcoal stripped fetal calf serum (Gemini Bio-Products, Woodland, CA, USA), $50 \mathrm{U} / \mathrm{ml}$ penicillin and $50 \mu \mathrm{g} / \mathrm{ml}$ streptomycin (GIBCO/BRL, Carlsbad, CA, USA). The cells were plated at a density of $10^{5} / \mathrm{cm}^{2}$ in 12-well plates (Nunc, Nalge Nunc International,
Rochester, NY, USA) and maintained at $34{ }^{\circ} \mathrm{C}$ with $5 \% \mathrm{CO}_{2}$. After 2 days of incubation, the cell identity was determined by $3 \beta$-hydroxysteroid dehydrogenase $(3 \beta-\mathrm{HSD})$ staining as well as testosterone induction.

\section{Histochemical staining of $3 \beta-H S D$ and testosterone induction assay}

For $3 \beta-H S D$ staining, cells were incubated in $50 \mathrm{mM}$ PBS, $\mathrm{pH} 7 \cdot 4$ containing $0 \cdot 2 \mathrm{mg} / \mathrm{ml}$ nitro-blue tetrazolium (GIBCO/BRL), $1 \mathrm{mg} / \mathrm{ml} \mathrm{NAD}$ and $0.12 \mathrm{mg} / \mathrm{ml}$ dehydroepiandrosterone (Sigma) for $90 \mathrm{~min}$ at $34^{\circ} \mathrm{C}$. The positive cells were stained a dark blue color. For the testosterone induction assay, the cells were exposed to $10 \mathrm{ng} / \mathrm{ml}$ human chorionic gonadotropin (hCG) for $24 \mathrm{~h}$. The conditioned media were assayed for testosterone content using a testosterone ELISA kit (ICN Pharmaceuticals, NY, USA) according to the manufacturer's instructions. Briefly $25 \mu \mathrm{l}$ sample/standard, $100 \mu \mathrm{l}$ testosterone-horseradish peroxidase (HRP) conjugate reagent and $50 \mu \mathrm{l}$ rabbit anti-testosterone reagent were mixed sequentially in wells and incubated at $37^{\circ} \mathrm{C}$ for $90 \mathrm{~min}$. The wells were then rinsed five times with distilled water, mixed with $100 \mu \mathrm{l}$ 3,3',5,5'-tetramethylbenzidine (TMB) solution, followed by $20 \mathrm{~min}$ incubation at $22{ }^{\circ} \mathrm{C}$. The reaction was stopped and absorbance was read at $450 \mathrm{~nm}$ within $15 \mathrm{~min}$.

\section{Cell treatment}

Two-day cultured Leydig cells grown in phenol red-free DMEM/F12 supplemented with 10\% charcoal stripped fetal bovine serum and antibiotics $(50 \mathrm{U} / \mathrm{ml}$ penicillin and $50 \mu \mathrm{g} / \mathrm{ml}$ streptomycin) were exposed for $24 \mathrm{~h}$ to one of the following treatments: (i) $1-50 \mathrm{ng} / \mathrm{ml} \mathrm{hCG} \mathrm{(Sigma);} \mathrm{(ii)}$ 0.2-2000 pg/ml TCDD (Cambridge Isotope Laboratories Inc., Andover, MA, USA); (iii) hCG $(1-50 \mathrm{ng} / \mathrm{ml})+$ TCDD $(0 \cdot 2-2000 \mathrm{pg} / \mathrm{ml})$; (iv) $2 \mathrm{mM}$ dibutyryl cAMP (dbcAMP) (Calbiochem) + TCDD (200 or 2000 pg/ml)+ hCG $(5$ or $10 \mathrm{ng} / \mathrm{ml})$; (v) hCG $(1-50 \mathrm{ng} / \mathrm{ml})+0 \cdot 1 \mu \mathrm{M}$ dexamethasone (DEX) (Calbiochem, San Diego, CA, USA); and (vi) dimethylsulfoxide (DMSO) (Sigma) solvent control. Cell viability was determined by the MTT (3-(4,5-dimethylthiazol-2-yl)-2,5-diphenyl tetrazolium bromide) reduction method. The viability of the control and treated cells was over $90 \%$.

The treated cells were used for the measurement of mRNAs for steroidogenic acute regulatory protein (StAR), cytochrome P450 side-chain cleavage enzyme (P450scc), $3 \beta-H S D-1$, cytochrome P450-17 $\alpha$ enzyme (CYP17 $\alpha$ ), CYP1A1 and glyceraldehyde-3-phosphate dehydrogenase (GAPDH). Conditioned media were assayed for progesterone and testosterone.

\section{Progesterone determination}

The conditioned media were assayed for progesterone content using a progesterone ELISA kit 
(ICN Pharmaceuticals) according to the manufacturer's instructions. Briefly $25 \mu \mathrm{l}$ sample/standard, $100 \mu \mathrm{l}$ working progesterone-HRP conjugate reagent and $50 \mu$ rabbit anti-progesterone reagent were mixed sequentially in the wells and incubated at $22{ }^{\circ} \mathrm{C}$ for $90 \mathrm{~min}$. The wells were rinsed five times with distilled water and mixed with $100 \mu \mathrm{l}$ TMB solution followed by $20 \mathrm{~min}$ incubation at $22{ }^{\circ} \mathrm{C}$. The reaction was then stopped and the absorbance was read at $450 \mathrm{~nm}$ within $15 \mathrm{~min}$.

\section{Effects of TCDD on mRNA levels of steroidogenic enzymes} and $C Y P 1 A 1$

StAR, P450scc, 3 $\beta$-HSD-1, CYP17 $\alpha$, CYP1A1 and GAPDH PCR products were generated by PCR of total RNA derived from the isolated Leydig cells. The primers were designed on the basis of the published sequence of StAR (GCAGCAGGCAACCTGGTG-forward and TG ATTGTCTTCGGCAGCC-reverse) (Ronen-Fuhrmann et al. 1998); P450scc (CCTCT GGTAATACTGGTG ATAGGC-forward and AGCTGGGCAACATGGAG TCA-reverse); 3 $\beta$-HSD-1 (ACTGGCAAATTCTCCA TAGCC-forward and TTCCTCCCAGCTGACAA GTGG-reverse) (Dasmahapatra et al. 2000); CYP17 $\alpha$ (CAGGAAGCCAAGTCACTGTGT-forward and TGT TGAAGCAGATAGCACAGATGA-reverse); CYP1A1 (CCTCTTTGGAGCTGGGTTTG-forward and TGC TGTGGGGGATGGTGAAG-reverse); and GAPDH (ATGGTGAAGGTCGTGTGAAC-forward and TCC ACCACCCTGTTGCTGT A-reverse). The PCR fragments for StAR (246 bp), P450scc (200 bp), 3 $\beta-H S D-1$ (405 bp), CYP17 $\alpha$ (150 bp), CYP1A1 (230 bp), and GAPDH (200 bp) were purified, subcloned into pCRIITOPO (Invitrogen) and subjected to dideoxy sequencing for verification. The purified plasmids were quantified and the respective copy numbers were calculated.

\section{Real-time PCR}

The treated cells were dissolved in TRIZOL Reagent (GIBCO/BRL) and total RNA was extracted according to the manufacturer's instructions. Purified RNA with a 1.6-1.8 $\mathrm{A}_{260} / \mathrm{A}_{280}$ ratio was used in this study. Real-time PCR was conducted for mRNA quantification. Briefly, $1 \mu \mathrm{g}$ total cellular RNA was reverse transcribed using an iScript cDNA synthesis kit (BioRad). Quantified standards $\left(10^{4}-10^{8}\right)$ and sample cDNA were analyzed by an iCycler iQ real-time PCR detection system using iQ SYBR Green Supermix (Bio-Rad). The copy number for each sample was calculated and the data were normalized using the expression level of GAPDH mRNA. The PCR conditions were $95^{\circ} \mathrm{C}$ for $3 \mathrm{~min}$ and 40 cycles of $95^{\circ} \mathrm{C}$ for $30 \mathrm{~s}, 56^{\circ} \mathrm{C}$ for $30 \mathrm{~s}$ and $72{ }^{\circ} \mathrm{C}$ for $1 \mathrm{~min}$. Fluorescent signals were captured at $82{ }^{\circ} \mathrm{C}$, the occurrence of primer dimers and secondary products was inspected using melting curve analysis. Control amplifications were done either without RT or without RNA. Following PCR amplification, the reaction products were run at $100 \mathrm{~V}$ on a $1 \%$ agarose gel with $0.5 \mu \mathrm{g} / \mathrm{ml}$ ethidium bromide to determine product specificity. All glass- and plastic-ware were treated with diethyl pyrocarbonate and autoclaved.

\section{Western blot analysis}

The treated cells were washed with two or three changes of cold PBS. Adherent cells were scraped from the plastic surface and transferred to a microcentrifuge tube. The cells were pelleted and resuspended in 30-50 $\mu$ cold lysis buffer containing $250 \mathrm{mM}$ Tris- $\mathrm{HCl}, \mathrm{pH} 8 \cdot 0,1 \% \mathrm{NP}-40$ and $150 \mathrm{mM} \mathrm{NaCl}$. After $10 \mathrm{~min}$ incubation on ice, the lysed cells were pelleted and supernatants were assayed for protein concentration (DC Protein Assay Kit II; Bio-Rad Pacific Ltd). Samples were subjected to electrophoresis in NuPage 4-12\% Bis-Tris gradient gels (Invitrogen). Gels were blotted onto a PVDF membrane. Western blotting was conducted using rabbit antibodies to P450scc (Chemicon Int., Temecula, CA, USA), followed by incubation with HRP-conjugated goat anti-rabbit antibody and was developed with chemiluminescent reagent (Western-lightening Plus; PerkinElmer Life Sciences, Boston, MA, USA). The blot was then washed in PBS and was re-probed with rabbit anti-actin antibody (Sigma).

\section{cAMP measurement}

Cells were exposed for $1.5 \mathrm{~h}$ to one of the following treatments: (i) $5 \mathrm{ng} / \mathrm{ml} \mathrm{hCG}$; (ii) hCG+TCDD (200 or $2000 \mathrm{pg} / \mathrm{ml}$ ); or (iii) DMSO solvent control. Cell lysates prepared in $0 \cdot 1 \mathrm{M} \mathrm{HCl}$ were used for cAMP measurement according to the manufacturer's instructions with a cAMP immunoassay kit (R\&D Systems, Minneapolis, MN, USA).

\section{Statistical analysis}

Drugs treatments were performed in triplicate in the same experiments and individual experiments were repeated at least three times. All data are represented as means \pm S.E. Statistical significance was tested by Student's $t$-test. Groups were considered significantly different if $P<0 \cdot 05$.

\section{Results}

\section{Characterization of the isolated Leydig cell model}

The four-step Percoll gradient centrifugation yielded cells of three major populations. The top layer (layer-1, $\rho \sim 1.035 \mathrm{~g} / \mathrm{ml})$ consisted of small round cells and cell debris. Layer-2 $(\rho \sim 1.076 \mathrm{~g} / \mathrm{ml})$ was composed of spermatozoa and a small fraction of Leydig cells. The cells in 

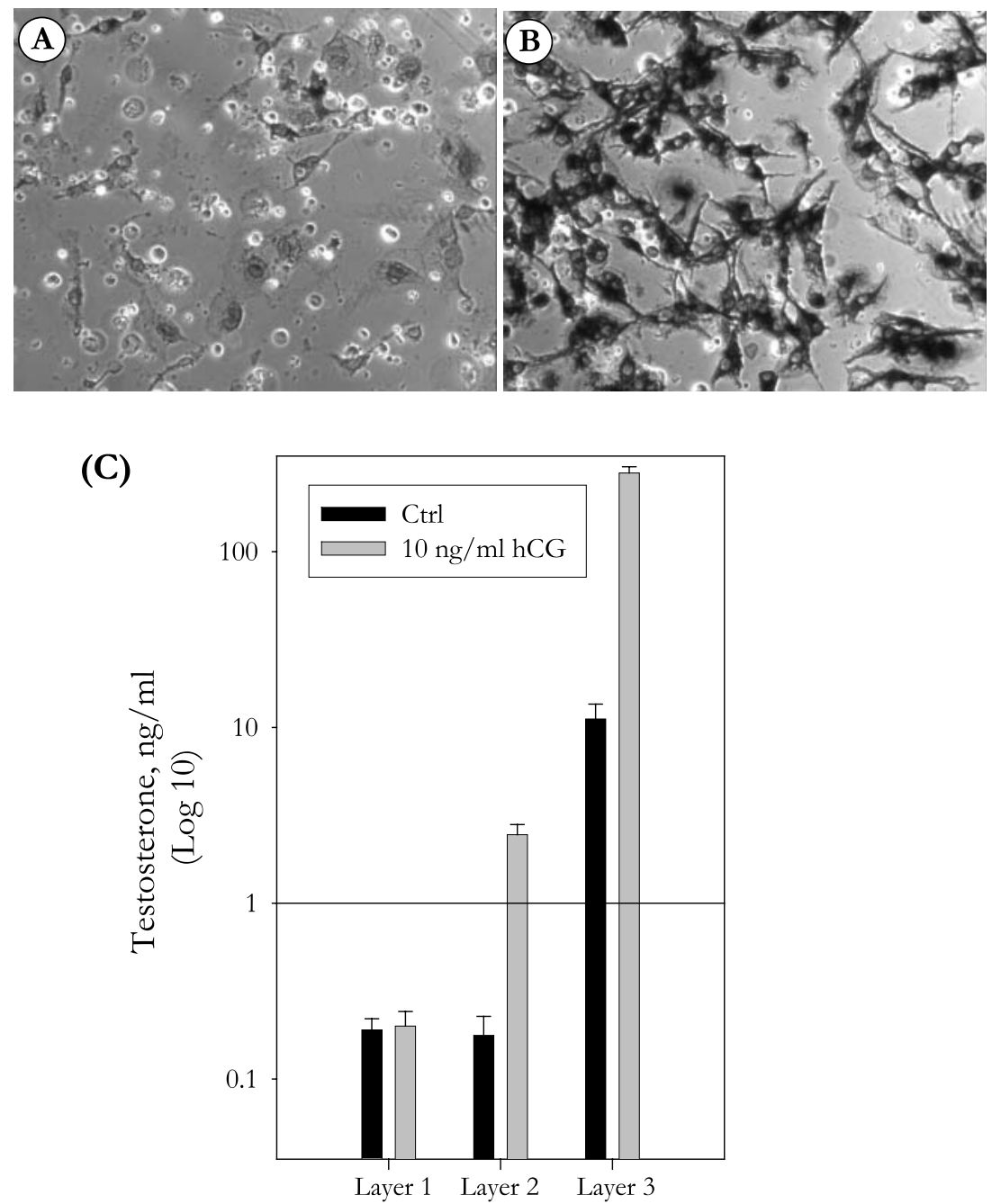

Figure 1 Histochemical staining of $3 \beta-\mathrm{HSD}$, and hCG-induced testosterone secretion in isolated rat testicular cells. No or little staining was found in the layer-2 cells (A). The layer-3 cells (B) were intensely stained for 3 $\beta$-HSD activity. (C) The basal and hCG $(10 \mathrm{ng} / \mathrm{ml})$-stimulated testosterone secretion levels in conditioned media of the isolated cells. Note that the layer-3 cells were highly stimulated, whereas the layer- 1 and -2 cells showed no and moderate responses respectively. Data (means \pm S.E.M.) are from four separate experiments. Note that the $y$-axis is on a log 10 scale.

the third layer $(\rho \sim 1 \cdot 085 \mathrm{~g} / \mathrm{ml})$ were over $90 \%$ Leydig cells, as they were positively stained by the $3 \beta-\mathrm{HSD}$ method (Fig. 1A and B). The basal testosterone secretion level of the layer-3 cells was about 55 -fold higher than that of layer-1 and -2 cells (Fig. 1C). The layer-3 cells were also highly sensitive to hCG stimulation, in which over a 25 -fold induction of testosterone secretion was detected. Layer-1 and -2 cells, however, showed no or moderate responses to the stimulation. According to the $3 \beta-\mathrm{HSD}$ staining and testosterone induction assay, the layer- 3 cells were confirmed as Leydig cells and were used for the latter part of the study.
Effect of TCDD on testosterone secretion of hCG-treated Leydig cells

Treatment of the Leydig cell culture with different doses of hCG $(1-50 \mathrm{ng} / \mathrm{ml})$ produced a dose-response induction curve of testosterone secretion (Fig. 2A). Significant reduction of testosterone secretion was detected in cells co-treated with 5 or $10 \mathrm{ng} / \mathrm{ml}$ hCG and 200 or $2000 \mathrm{pg} / \mathrm{ml}$ TCDD (Fig. 2B). However, there were no significant change in the $\mathrm{ED}_{50}$ and $\mathrm{V}_{\max }$ response of the cells to hCG stimulation. The profile of inhibition was different from the action of DEX, whereas the $\mathrm{ED}_{50}$ were 
considerably reduced (Fig. 3). Intriguingly the TCDDmediated reduction of testosterone secretion can be counteracted by a higher dose of hCG $(50 \mathrm{ng} / \mathrm{ml})$ cotreatment. The countereffect can also be imitated by $2 \mathrm{mM}$ dbcAMP (data not shown). To elucidate the
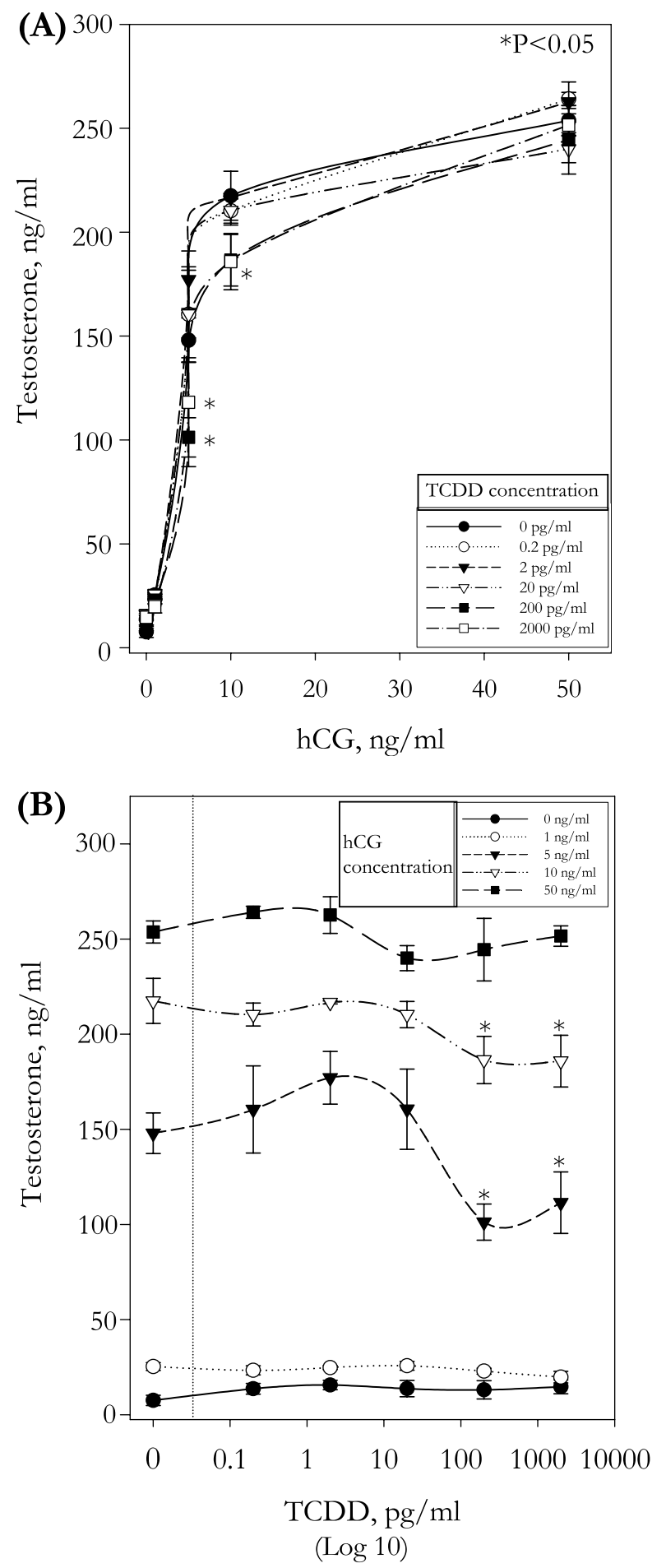

www.endocrinology-journals.org

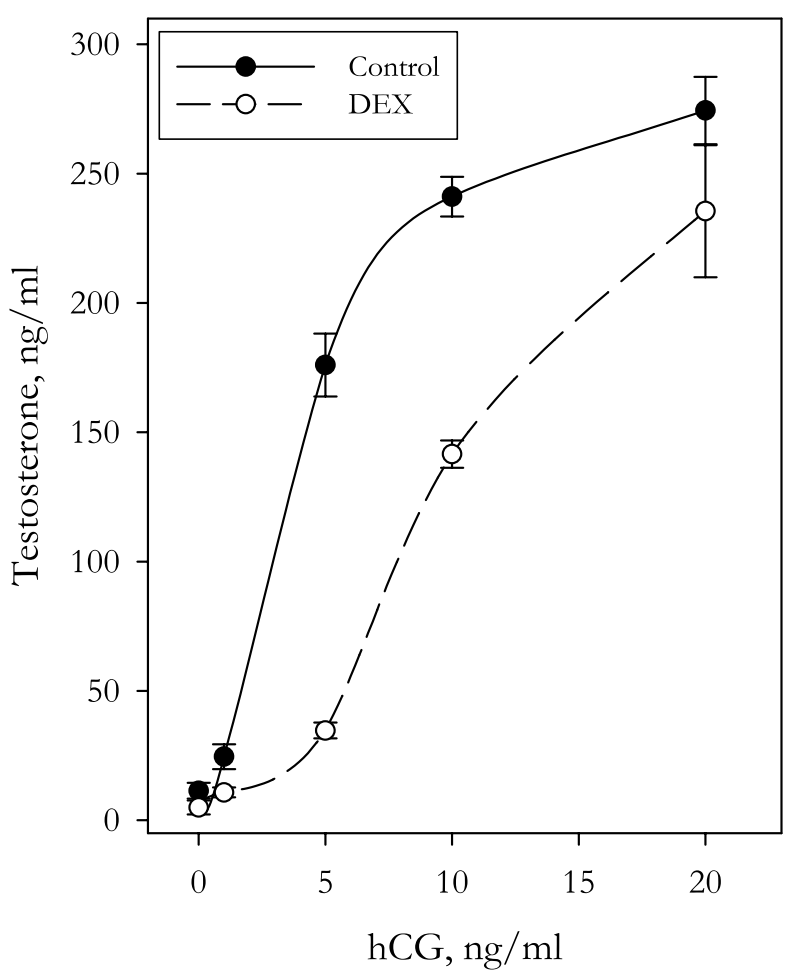

Figure 3 Effect of DEX on testosterone secretion in hCG-induced rat Leydig cells. The cells were incubated for $24 \mathrm{~h}$ in $10 \%$ charcoal dextran stripped serum/DMEM/F12 (1:1) containing DEX $(0 \cdot 1 \mu \mathrm{M})$. Significant reductions of testosterone secretion and an increase in $\mathrm{ED}_{50}$ response to hCG stimulation were found. Data (means \pm S.E.M.) are from three separate experiments.

underlying mechanism of the TCDD-elicited reduction of testosterone secretion, we measured the mRNA expression levels of some key steroidogenic enzymes, including StAR, P450scc, 3 $\beta-\mathrm{HSD}-1$ and CYP17 $\alpha$ using the real-time PCR method (Fig. 4A). In the hCG-treated cells, expression of the steroidogenic enzymes was significantly stimulated. In the co-treatment with 200 or $2000 \mathrm{pg} / \mathrm{ml}$ TCDD and 5 or $10 \mathrm{ng} / \mathrm{ml} \mathrm{hCG}$, TCDD significantly reduced the expression of $\mathrm{P} 450 \mathrm{scc}(-70 \%)$. A decrease in protein level was consistently demonstrated

Figure 2 Testosterone induction curves upon hCG or hCG+TCDD treatment in rat Leydig cell cultures. The cells were incubated for $24 \mathrm{~h}$ in $10 \%$ charcoal dextran stripped serum/DMEM/F12 (1:1) containing different doses of hCG $(1-50 \mathrm{ng} / \mathrm{ml})$. A dose-response induction curve of testosterone secretion is shown in (A). When the hCG-stimulated cells were co-treated with an increasing dose of TCDD $(0 \cdot 2-2000 \mathrm{pg} / \mathrm{ml})$, no change in the $\mathrm{ED}_{50}$ and $\mathrm{V}_{\max }$ responses to hCG stimulation were observed. However, significant reductions of testosterone secretion were measured at the conditions of 5 or $10 \mathrm{ng} / \mathrm{ml} \mathrm{hCG}$ and 200 or $2000 \mathrm{pg} / \mathrm{ml} \mathrm{TCDD}$ co-treatments (B). Data (means \pm S.E.M.) are from three separate experiments. TCDD-suppressed hCG-induced testosterone secretion was significant $\left({ }^{\star} P<0 \cdot 05\right)$ as compared with the corresponding hCG-alone treatment. 
(A)

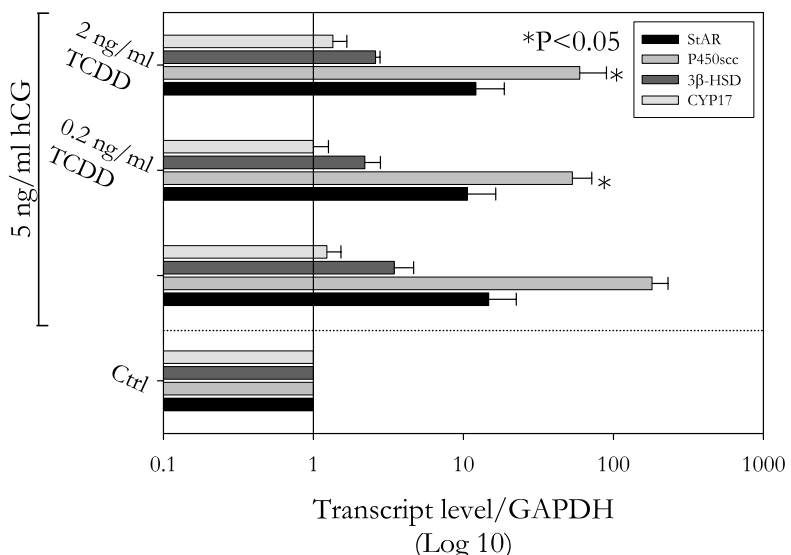

(B)

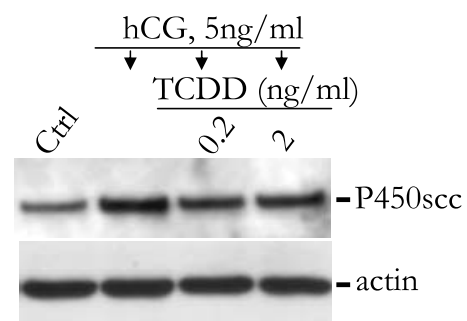

(C)

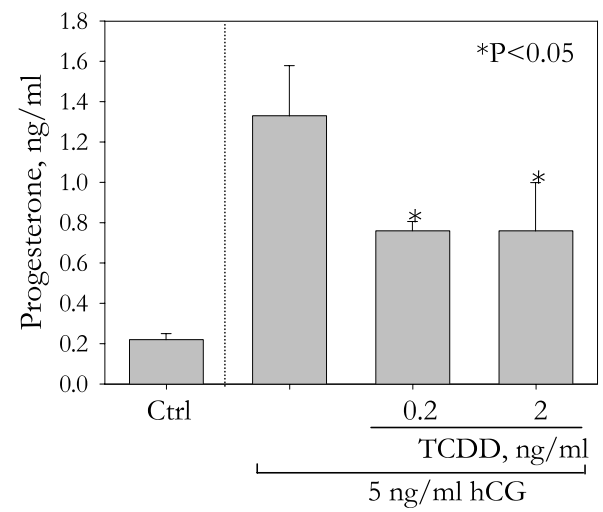

Figure 4 Effect of hCG and hCG+TCDD on (A) the mRNA expressions of selected steroidogenic enzymes (i.e. StAR, P450scc, $3 \beta$-HSD-1 and CYP17 $\alpha$ ), (B) P450scc protein levels and (C) progesterone levels of the rat Leydig cell culture. The cells were incubated for $24 \mathrm{~h}$ in $10 \%$ charcoal dextran stripped serum/DMEM/F12 (1:1) containing $5 \mathrm{ng} / \mathrm{ml} \mathrm{hCG} \mathrm{and} \mathrm{hCG}+0 \cdot 2$ or $2 \mathrm{ng} / \mathrm{ml} \mathrm{TCDD}$. (A) For real-time PCR, total RNA of each sample was reverse-transcribed and analyzed by an iCycler iQ real-time PCR detection system using iQ SYBR Green Supermix. P450scc mRNA levels in hCG+TCDD-treated cells were significantly $\left({ }^{*} P<0 \cdot 05\right)$ reduced. Note that the $x$-axis is on a log 10 scale. $(B, C)$ Significant reduction of $\mathrm{P} 450 \mathrm{scc}$ and progesterone levels were detected after TCDD+hCG co-treatment $\left({ }^{*} P<0 \cdot 05\right)$. Data (means \pm S.E.M.) are from three separate experiments.

by Western blotting (Fig. 4B). Since P450scc mediated the synthesis of progesterone, we assayed the progesterone levels in the conditioned media of the TCDD/hCG co-treated cells. Consistently there was a significant reduction of progesterone levels in the cells (Fig. 4C).

It is well know that Leydig cell steroidogenesis can be stimulated by luteinizing hormone (LH), whereas cAMP plays an important role in the regulation (Pon et al. 1986, Pon \& Orme-Johnson 1986, Epstein \& Orme-Johnson 1991, Clark et al. 1995, Luo et al. 1998). To determine if TCDD treatment can modulate cellular cAMP levels, we measured its levels in hCG and hCG/TCDD co-treated cells. Elevated cellular cAMP levels were measured at $1 \mathrm{~h}$ after hCG treatment. The maximal elevated level was detected at 1.5-2 $\mathrm{h}$ after treatment (Fig 5A). Treatment of the hCG-induced cells with 200 and $2000 \mathrm{pg} / \mathrm{ml}$ TCDD significantly reduced the cellular cAMP level $(P<0 \cdot 05)$ (Fig. 5B). A significant reduction of $\mathrm{P} 450 \mathrm{scc}$ protein level was detectable at $8 \mathrm{~h}$ after TCDD/hCG treatment (Fig. 5C).

\section{Discussion}

Our previous studies have demonstrated effects of TCDD in modulating the expression of Sertoli cell secretory products (i.e. Müllerian inhibiting factor, $17 \beta$-estradiol) and markers (i.e. sertolin and testin) for cell-cell interaction (Lai et al. 2005). The studies suggested that TCDD exposure can interfere with intercellular communication and possibly disrupt the process of spermatogenesis. These findings prompted the present investigation to examine possible effects of TCDD on Leydig cell functions, particularly for the synthesis and secretion of testosterone. In the first part of this study, the modulating effects of TCDD on hCG-induced testosterone secretion were examined. Treatment of the cells with hCG produced a doseresponse curve of testosterone induction. In the cotreatment studies using doses of 0.2 or $2 \mathrm{ng} / \mathrm{ml}$ TCDD and 5 or $10 \mathrm{ng} / \mathrm{ml} \mathrm{hCG}$, a significant reduction of progesterone $(43 \%)$ and testosterone $(32 \%)$ levels was observed. The TCDD-mediated reduction of progesterone and testosterone production, however, can be completely abolished at a higher dose $(50 \mathrm{ng} / \mathrm{ml})$ of hCG treatment. This observation is in agreement with other reports using animal models, whereas high doses of hCG could alleviate TCDD-mediated inhibition of Leydig cell functions (Wilker et al. 1995, Mandal et al. 2001) and prevented the TCDD-elicited reduction of cytochrome P450 enzymes (Ruangwises et al. 1991). To delineate the underlying mechanism of TCDD-mediated inhibition of testosterone synthesis, we measured the changes in the expression of some key steroidogenic enzymes. Our results demonstrated that there was a $70 \%$ reduction of $\mathrm{P} 450 \mathrm{scc}$ mRNA levels in the TCDD/hCG co-treated cells. Similar findings were observed in mice that were i.p. administrated with $100 \mathrm{ng} / \mathrm{g}$ TCDD (Fukuzawa et al. 2004). The TCDD-mediated inhibition of steroidogenic 


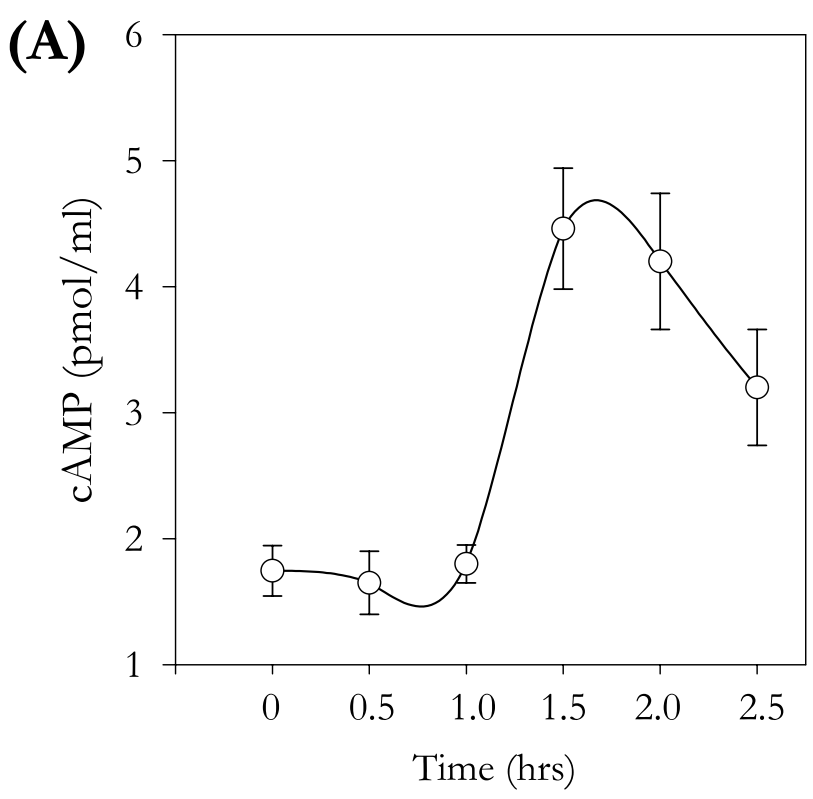

(C)

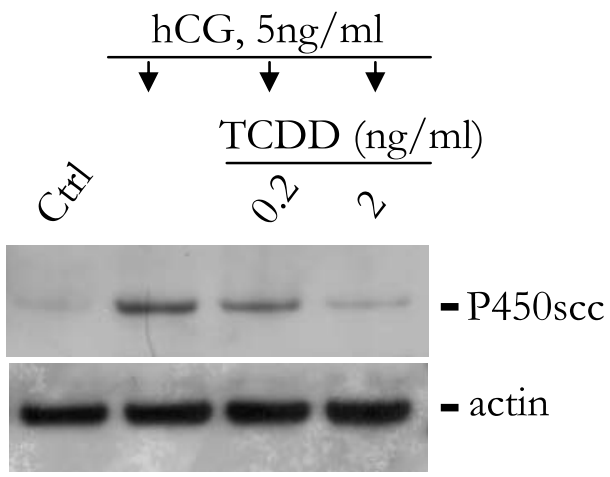

enzymatic activities seems not to be gender specific, as a P450scc mRNA reduction in TCDD $(3 \cdot 1 \mathrm{nM})$-exposed rat primary granulosa cells was reported (Dasmahapatra et al. 2000).

In this study, we observed that the effective dose of TCDD to modulate Leydig cell functions falls in the $\mathrm{ng} / \mathrm{ml}$ level. The molar concentrations for $0 \cdot 2$ and $2 \mathrm{ng} / \mathrm{ml}$ used in this study are equivalent to 0.62 and $6.2 \mathrm{nM}$ respectively. The concentrations of TCDD used are comparable or even lower than other reports that had demonstrated the inhibitory effect of TCDD on Leydig cell function or testosterone production in animal models (Rune et al. 1991b, Chahoud et al. 1992, Johnson et al. 1992, 1994, Mably et al. 1992, Peterson et al. 1993, Wilker et al. 1995, Latchoumycandane et al. 2002a,b). In addition, it is comparable to others' cell-culture systems where nanomolar levels of TCDD exposure were needed to cause noticeable effects on signaling molecules (Shibazaki et al. 2004, Vogel et al. 2004).

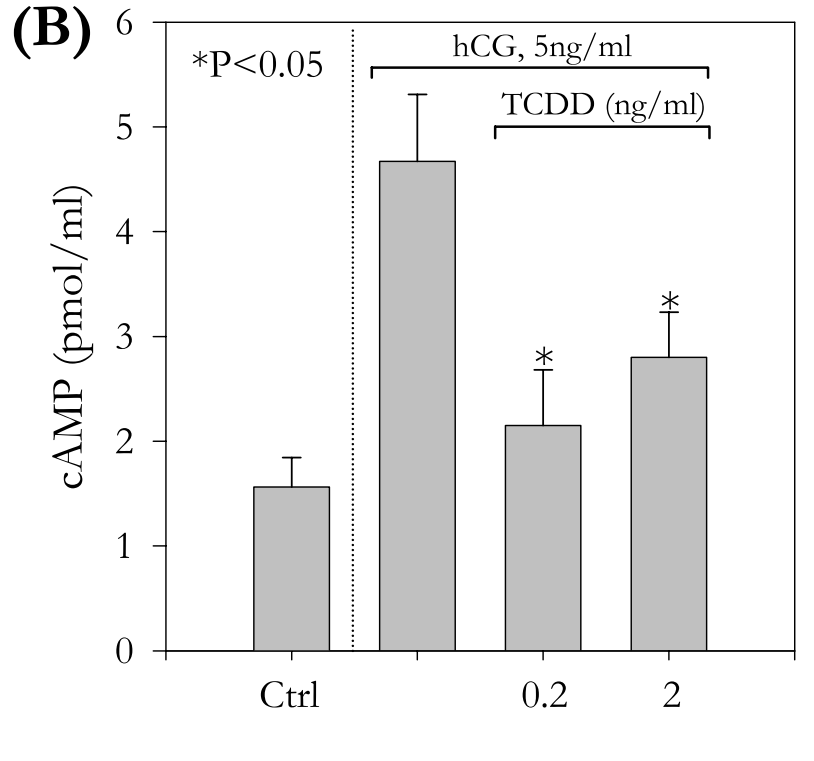

Figure 5 (A) Time course induction of cAMP in hCG-treated rat Leydig cells. (B) Effect of TCDD exposure on cAMP levels of the hCG-induced Leydig cells at $1.5 \mathrm{~h}$ after treatment. (C) Western blotting analysis of P450scc protein levels in Leydig cells at $8 \mathrm{~h}$ after treatment. Significant reduction of cellular cAMP and P450scc protein levels were detected after TCDD+hCG co-treatment $\left({ }^{*} P<0 \cdot 05\right)$. Data (means \pm S.E.M.) are from three separate experiments.

In the present study, we have demonstrated that TCDD-mediated inhibition can be completely impeded by higher dose of hCG co-treatment. Consistently, the hCG countereffect can be imitated by cAMP treatment. These results shed light onto the possible mechanistic action of TCDD in interfering with the process of steroidogenesis. With the benefit of hindsight, we measured and compared the change of cellular cAMP levels in hCG and TCDD/hCG co-treated Leydig cells. Intriguingly we can detect an acute cellular effect of TCDD at $2 \mathrm{~h}$ after treatment in hCG co-treated cells, whereas the cellular cAMP level was significantly reduced. Accompanying this early event, a significant reduction of P450scc protein levels was measured.

Hitherto, our data demonstrated that the significant reduction of the secreted progesterone and testosterone levels in the Leydig cells were attributed to the reduced expression of $\mathrm{P} 450 \mathrm{scc}$. It is a rate-limiting enzyme mediating the conversion of cholesterol to pregnenolone 
(Stocco 2001). It is likely that the reduced enzyme level was due to the decrease of cellular cAMP at the early phase of hCG stimulation. In a mouse fibroblast model, Vogel et al. (2004) had demonstrated that the effect of TCDD on cellular cAMP level was AhR-dependent, whereas the binding of the immunophilin-like protein (XAP2) to cAMP-specific phosphodiesterase (PDE4A5) modulated cAMP signaling. Other studies had also proposed that the effect of TCDD on steroidogenic enzymes was AhR-dependent (Sugawara et al. 2001, Fukuzawa et al. 2004). Taken together, we suggest that the TCDDmediated reduction of cellular cAMP levels in this study is possibly AhR-dependent. The potential roles of $\mathrm{LH}$ receptor, adenylate cyclase or cAMP-specific phosphodiesterase in the mechanistic action of TCDD have not been addressed in this study.

\section{Funding}

This work was supported by Group Research-Central Allocation of the Research Grants Council, University Grants Committee of Hong Kong and the Faculty Research Grant (FRG 02-03/I-01), Hong Kong Baptist University (to $\mathrm{C} \mathrm{K} \mathrm{C} \mathrm{W).} \mathrm{The} \mathrm{authors} \mathrm{declare} \mathrm{that} \mathrm{there}$ is no conflict of interest that would prejudice the impartiality of this scientific work.

\section{References}

Biegel LA, Cook JC \& Hurtt ME (1993) Isolation and primary culture of Leydig cells. In Male Reproductive Toxicology, vol 3A, ch 11, pp 182-196. Eds RE Chapin \& JJ Heindel. San Diego, CA: Academic Press.

Bjerke DL \& Peterson RE 1994 Reproductive toxicity of 2,3,7,8tetrachlorodibenzo-p-dioxin in male rats: different effects of in utero versus lactational exposure. Toxicology and Applied Pharmacology 127 241-249.

Chahoud I, Hartmann J, Rune GM \& Neubert D 1992 Reproductive toxicity and toxicokinetics of 2,3,7,8-tetrachlorodibenzo-p-dioxin. 3. Effects of single doses on the testis of male rats. Archives of Toxicology 66 567-572.

Clark BJ, Soo SC, Caron KM, Ikeda Y, Parker KL \& Stocco DM 1995 Hormonal and developmental regulation of the steroidogenic acute regulatory protein. Molecular Endocrinology 9 1346-1355.

Dasmahapatra AK, Wimpee BA, Trewin AL, Wimpee CF, Ghorai JK \& Hutz RJ 2000 Demonstration of 2,3,7,8-tetrachlorodibenzo- $p$ dioxin attenuation of $\mathrm{P} 450$ steroidogenic enzyme mRNAs in rat granulosa cell in vitro by competitive reverse transcriptasepolymerase chain reaction assay. Molecular and Cellular Endocrinology 164 5-18.

Dohr O, Li W, Donat S, Vogel C \& Abel J 1996 Aryl hydrocarbon receptor mRNA levels in different tissues of $2,3,7,8$ tetrachlorodibenzo- $p$-dioxin-responsive and nonresponsive mice. Advances in Experimental Medicine and Biology 387 447-459.

Epstein LF \& Orme-Johnson NR 1991 Acute action of luteinizing hormone on mouse Leydig cells: accumulation of mitochondrial phosphoproteins and stimulation of testosterone synthesis. Molecular and Cellular Endocrinology 81 113-126.

Faqi AS, Dalsenter PR, Merker HJ \& Chahoud I 1998 Reproductive toxicity and tissue concentrations of low doses of 2,3,7,8tetrachlorodibenzo- $p$-dioxin in male offspring rats exposed throughout pregnancy and lactation. Toxicology and Applied Pharmacology 150 383-392.

Fukuzawa NH, Ohsako S, Wu Q, Sakaue M, Fujii-Kuriyama Y, Baba T \& Tohyama C 2004 Testicular cytochrome P450scc and LHR as possible targets of 2,3,7,8-tetrachlorodibenzo- $p$-dioxin (TCDD) in the mouse. Molecular and Cellular Endocrinology 221 87-96.

Gray LE Jr, Kelce WR, Monosson E, Ostby JS \& Birnbaum LS 1995 Exposure to TCDD during development permanently alters reproductive function in male Long Evans rats and hamsters: reduced ejaculated and epididymal sperm numbers and sex accessory gland weights in offspring with normal androgenic status. Toxicology and Applied Pharmacology 131 108-118.

Johnson L, Dickerson R, Safe SH, Nyberg CL, Lewis RP \& Welsh TH Jr 1992 Reduced Leydig cell volume and function in adult rats exposed to 2,3,7,8-tetrachlorodibenzo-p-dioxin without a significant effect on spermatogenesis. Toxicology 76 103-118.

Johnson L, Wilker CE, Safe SH, Scott B, Dean DD \& White PH 1994 2,3,7,8-Tetrachlorodibenzo-p-dioxin reduces the number, size, and organelle content of Leydig cells in adult rat testes. Toxicology 89 49-65.

Lai KP, Wong MH \& Wong CK 2005 Effects of TCDD in modulating the expression of Sertoli cell secretory products and markers for cell-cell interaction. Toxicology 206 111-123.

Latchoumycandane C, Chitra C \& Mathur P 2002a Induction of oxidative stress in rat epididymal sperm after exposure to 2,3,7,8-tetrachlorodibenzo- $p$-dioxin. Archives of Toxicology 76 $113-118$.

Latchoumycandane C, Chitra KC \& Mathur PP $2002 b$ The effect of 2,3,7,8-tetrachlorodibenzo- $p$-dioxin on the antioxidant system in mitochondrial and microsomal fractions of rat testis. Toxicology 171 127-135.

Li X, Johnson DC \& Rozman KK 1995 Reproductive effects of 2,3,7,8-tetrachlorodibenzo-p-dioxin (TCDD) in female rats: ovulation, hormonal regulation, and possible mechanism(s). Toxicology and Applied Pharmacology 133 321-327.

Luo L, Chen H, Stocco DM \& Zirkin BR 1998 Leydig cell protein synthesis and steroidogenesis in response to acute stimulation by luteinizing hormone in rats. Biology of Reproduction 59 263-270.

Mably TA, Bjerke DL, Moore RW, Gendron-Fitzpatrick A \& Peterson RE 1992 In utero and lactational exposure of male rats to 2,3,7,8-tetrachlorodibenzo-p-dioxin. 3. Effects on spermatogenesis and reproductive capability. Toxicology and Applied Pharmacology 114 $118-126$.

Mandal PK, McDaniel LR, Prough RA \& Clark BJ 2001 7,12-Dimethylbenz[a]anthracene inhibition of steroid production in MA-10 mouse Leydig tumor cells is not directly linked to induction of CYP1B1. Toxicology and Applied Pharmacology 175 200-208.

Matsushita N, Sogawa K, Ema M, Yoshida A \& Fujii-Kuriyama Y 1993 A factor binding to the xenobiotic responsive element (XRE) of P-4501A1 gene consists of at least two helix-loop-helix proteins, Ah receptor and Arnt. Journal of Biological Chemistry 268 21002-21006.

Peterson RE, Theobald HM \& Kimmel GL 1993 Developmental and reproductive toxicity of dioxins and related compounds: cross-species comparisons. Critical Reviews in Toxicology 23 283-335.

Pon LA \& Orme-Johnson NR 1986 Acute stimulation of steroidogenesis in corpus luteum and adrenal cortex by peptide hormones. Rapid induction of a similar protein in both tissues. Journal of Biological Chemistry 261 6594-6599.

Pon LA, Epstein LF \& Orme-Johnson NR 1986 Acute cAMP stimulation in Leydig cells: rapid accumulation of a protein similar to that detected in adrenal cortex and corpus luteum. Endocrine Research 12 429-446.

Reyes H, Reisz-Porszasz S \& Hankinson O 1992 Identification of the Ah receptor nuclear translocator protein (Arnt) as a component of the DNA binding form of the Ah receptor. Science 256 1193-1195. 
Ronen-Fuhrmann T, Timberg R, King SR, Hales KH, Hales DB, Stocco DM \& Orly J 1998 Spatio-temporal expression patterns of steroidogenic acute regulatory protein (StAR) during follicular development in the rat ovary. Endocrinology 139 303-315.

Ruangwises S, Bestervelt LL, Piper DW, Nolan CJ \& Piper WN 1991 Human chorionic gonadotropin treatment prevents depressed 17 alpha-hydroxylase/C17-20 lyase activities and serum testosterone concentrations in 2,3,7,8-tetrachlorodibenzo- $p$ dioxin-treated rats. Biology of Reproduction 45 143-150.

Rune GM, de Souza P, Krowke R, Merker HJ \& Neubert D 1991a Morphological and histochemical pattern of response in rat testes after administration of 2,3,7,8-tetrachlorodibenzo- $p$-dioxin (TCDD). Histology and Histopathology 6 459-467.

Rune GM, deSouza P, Krowke R, Merker HJ \& Neubert D $1991 b$ Morphological and histochemical effects of 2,3,7,8tetrachlorodibenzo- $p$-dioxin (TCDD) on marmoset (Callithrix jacchus) testes. Archives of Andrology 26 143-154.

Safe SH 1995 Modulation of gene expression and endocrine response pathways by $2,3,7,8$-tetrachlorodibenzo-p-dioxin and related compounds. Pharmacology and Therapeutics 67 247-281.

Salisbury TB \& Marcinkiewicz JL 2002 In utero and lactational exposure to 2,3,7,8-tetrachlorodibenzo- $p$-dioxin and 2,3,4,7,8pentachlorodibenzofuran reduces growth and disrupts reproductive parameters in female rats. Biology of Reproduction 66 1621-1626.

Schmidt JV \& Bradfield CA 1996 Ah receptor signaling pathways. Annual Review of Cell and Developmental Biology 12 55-89.

Shibazaki M, Takeuchi T, Ahmed S \& Kikuchi H 2004 Suppression by p38 MAP kinase inhibitors (pyridinyl imidazole compounds) of Ah receptor target gene activation by 2,3,7,8-tetrachlorodibenzo- $p$ - dioxin and the possible mechanism. Journal of Biological Chemistry 279 3869-3876.

Stocco DM 2001 StAR protein and the regulation of steroid hormone biosynthesis. Annual Review of Physiology 63 193-213.

Sugawara T, Nomura E, Sakuragi N \& Fujimoto S 2001 The effect of the arylhydrocarbon receptor on the human steroidogenic acute regulatory gene promoter activity. Journal of Steroid Biochemistry and Molecular Biology 78 253-260.

Theobald HM \& Peterson RE 1997 In utero and lactational exposure to 2,3,7,8-tetrachlorodibenzo-rho-dioxin: effects on development of the male and female reproductive system of the mouse. Toxicology and Applied Pharmacology 145 124-135.

Thomae TL, Glover E \& Bradfield CA 2004 A maternal Ahr null genotype sensitizes embryos to chemical teratogenesis. Journal of Biological Chemistry 279 30189-30194.

Vogel CF, Sciullo E, Park S, Liedtke C, Trautwein C \& Matsumura F 2004 Dioxin increases C/EBPbeta transcription by activating cAMP/protein kinase A. Journal of Biological Chemistry 279 8886-8894.

Wilker CE, Welsh TH Jr, Safe SH, Narasimhan TR \& Johnson L 1995 Human chorionic gonadotropin protects Leydig cell function against 2,3,7,8-tetrachlorodibenzo-p-dioxin in adult rats: role of Leydig cell cytoplasmic volume. Toxicology 95 93-102.

Received 23 February 2005

Accepted 4 March 2005 